\title{
Dynamics of phytoplankton succession in Tungabhadra River near Harihar, Karnataka (India)
}

\author{
B. Suresh ${ }^{1 *}$, S. Manjappa ${ }^{1}$ and E. T. Puttaiah ${ }^{2}$ \\ ${ }^{1}$ Chemistry and Environmental Science and Technology Study Centre, Bapuji Institute of \\ Engineering and Technology, Davangere-577004. Karnataka State, India. \\ ${ }^{2}$ University Mysore, Mysore, Karnataka State, India.
}

Accepted 7 June, 2013

\begin{abstract}
There has been a serious concern about declining water quality in the rivers and streams since 1960 . Wide varities of pollutants have been reported to cause deterioration of water quality in rivers. Tungabhadra River in Karnataka is an important tributary of Krishna. It has a drainage area of 71,417 sq. $\mathrm{km}$ out of which $57,671 \mathrm{sq}$. $\mathrm{km}$ area lies in the state of Karnataka. The river covers the distance of 293 $\mathbf{k m}$ in the state. This river is considered as life line of this area, which fulfills the needs of hundreds of villages, situated at both sides of the river. The study was conducted to measure its various physicochemical and bacteriological parameters including levels of algal community. Pollution in water bodies may indicate the environment of algal nutrients in water. They may also function as indicators of pollution. Hence, the present investigation is an attempt to know the pollution load through algal indicators in Tungabhadra river of Karnataka near Harihar town. The study has been conducted from May 2004 to April 2005. The water and algal samples were collected at regular intervals of 15 days at four stations for one year. The most tolerant genera and species of four groups of algae namely, Chlorophyceae, Bacilariophyceae, Cyanophyceae and Euglenophyceae indicate that total algal population is $17,7159 \mathrm{o} / \mathrm{L}$ in station $\mathrm{S}_{3}$; which has the influence of industrial pollution from Harihar Polyfibre and Grasim industry situated on the bank of the river; which are discharging its treated effluent to this river. The population of algal species is $75,849 \mathrm{o} / \mathrm{L}$ at station $\mathrm{S}_{1}, 68,056 \mathrm{o} / \mathrm{L}$ station $\mathrm{S}_{2}$ and $38,915 \mathrm{o} / \mathrm{L}$ station $\mathrm{S}_{4}$. The correlation and inter correlation among the physico-chemical parameters along with phytoplankton groups have been made. The results obtained are tabulated and discussed.
\end{abstract}

Key words: Tungabhadra River, dynamics, phytoplankton, succession.

\section{INTRODUCTION}

Water is one of the most important precious natural resources required essentially for the survival and health of living organisms. In India, $80 \%$ of the surface water is exposed to pollution. Pollution taking place in surface water may bring about enrichment of algal nutrients in water. Surface water due to man's increased activities like sand mining, fishing, vehicle, cloth washings, the discharge of domestic wastes, solid waste, industrial waste discharge, agricultural runoff from surroundings areas which enter into the river bodies through different drains and channels of rivers may cause the river pollution. Tungabhadra River in Karnataka is an important tributary of Krishna. It has a drainage area of $71,417^{2} \mathrm{~km}$ out of which $57,671^{2} \mathrm{~km}$ lies in the state. It covers a distance of $293 \mathrm{~km}$ in the state and is getting polluted due to rapid industrial growth, domestic and 
Table 1. Average values of physico-chemical parameters at 4 stations of Tungabhadra River from May 2004 to April 2005

\begin{tabular}{lcccc}
\hline Parameter & Station S1 & Station S2 & Station S3 & Station S4 \\
\hline Temperature $\left({ }^{\circ} \mathrm{C}\right)$ & 29.00 & 28.50 & 30.00 & 29.50 \\
pH & 8.10 & 7.98 & 7.57 & 7.86 \\
Turbidity $(\mathrm{NTU})$ & 5.00 & 10.00 & 18.00 & 8.00 \\
Electrical conductivity $(\mu \mathrm{mohs} / \mathrm{cm})$ & 235.04 & 332.23 & 595.76 & 294.60 \\
Dissolved oxygen $(\mathrm{mg} / \mathrm{l})$ & 8.10 & 7.70 & 6.80 & 7.60 \\
Biological oxygen demand $(\mathrm{mg} / \mathrm{l})$ & 5.28 & 4.50 & 4.80 & 5.10 \\
Chemical oxygen demand $(\mathrm{mg} / \mathrm{l})$ & 66.92 & 81.33 & 186.42 & 94.50 \\
Nitrates $(\mathrm{mg} / \mathrm{l})$ & 8.46 & 4.86 & 9.00 & 2.71 \\
Chlorides $(\mathrm{mg} / \mathrm{l})$ & 35.22 & 45.94 & 146.94 & 51.00 \\
Sulphates $(\mathrm{mg} / \mathrm{l})$ & 7.67 & 9.25 & 14.82 & 8.45 \\
Total dissolved solids $(\mathrm{mg} / \mathrm{l})$ & 129.27 & 199.32 & 357.45 & 162.03 \\
Phosphates $(\mathrm{mg} / \mathrm{l})$ & 0.46 & 0.68 & 1.13 & 0.56 \\
Total hardness as CaCo $3(\mathrm{mg} / \mathrm{l})$ & 83.75 & 80.58 & 89.42 & 97.00 \\
Calcium as $\mathrm{Ca}(\mathrm{mg} / \mathrm{l})$ & 52.70 & 580.00 & 141.40 & 50.00 \\
Magnesium as $\mathrm{Mg}(\mathrm{mg} / \mathrm{l})$ & 31.00 & 36.00 & 48.00 & 47.00 \\
\hline
\end{tabular}

agricultural activities in the region. Pollution is as old as man himself, in prehistoric time, the population was very thin, the man used to move from place to place in search of food and better living. The district Davangere is located in the central part of Karnataka state (India) between latitude $14^{\circ} 17^{\prime}$ to $14^{\circ} 35^{\prime} \mathrm{N}$ and longitude $75^{\circ} 50^{\prime}$ to $76^{\circ}$ $05^{\prime} \mathrm{E}$ covering an area of $6500^{2} \mathrm{~km}$ at an average altitude of $540 \mathrm{~m}$ above Mean Sea Level (MSL). The river Tungabhadra is bifurcating the adjoining district namely Haveri. Four strategic locations are selected for the limnological studies of algae from various aquatic habitats of the lotic environment of the river has been made as studied extensively in India.

Research studies on the limnological aspects are of great significance in developing resources of a water body. The seasonal variations of physical - chemical factors have a profound effect on the distribution and population density of both fauna and flora (Hassan, 1998). The abundance of phytoplankton and zooplankton in the fresh water bodies is greatly regulated by the physico-chemical factors (Muhauser et al., 1995). The present study reports phytoplankton diversity in Tungabhadra River.

\section{MATERIALS AND METHODS}

The water and algal samples were collected at regular intervals of 15 days for one year. During the present investigation, four different stations were chosen on the basis of algal occurrence and human activities.

\section{Station $\left(\mathbf{S}_{1}\right)$}

The site of this habitat is located at the upstream before the river enters into city.

\section{Station $\left(\mathbf{S}_{2}\right)$}

This station is located on the main stream of river Tungabhadra in a place just near the confluence point of Sulekere stream (tributary).

\section{Station $\left(\mathrm{S}_{3}\right)$}

This station is located at the down stream of Harihar polyfibers effluent discharge (near Harlapura).

\section{Station $\left(\mathbf{S}_{4}\right)$}

This sampling station is located about $2 \mathrm{~km}$ away from confluence point $\left(\mathrm{S}_{2}\right)$.

\section{Sampling}

Physico-chemical analysis of water as per was done according to standard methods recommended by APHA (1995) and Trivedy and Goel (1986). Algae were preserved in 4\% formaldehyde for identification using key provided by Smith (1950), Prescott (1978) for Chlorophyceae and Euglenophyceae; Desikachary (1959) for Cyanophyceae and Hendey (1964) for Bacilleriophyceae (Table 6).

\section{Statistical analysis}

Correlation and inter correlation matrices were compared separately for the physico-chemical parameters and phytoplankton (s) (Table 6)

\section{RESULT AND DISCUSSION}

\section{Dissolved chemical parameters}

The average values of physico-chemical parameters at four stations of the river are shown in Table 1. The range 
Table 2. The range and average population of 4 groups of algal at 4 stations of Tungabhadra River from May 2004 to April 2005 (o/L).

\begin{tabular}{|c|c|c|c|c|c|c|c|c|c|}
\hline \multirow{3}{*}{ Station } & \multicolumn{8}{|c|}{ Algal group } & \multirow{3}{*}{ Total algal population (o/L) } \\
\hline & \multicolumn{2}{|c|}{ Chlorophyceae } & \multicolumn{2}{|c|}{ Cyanaophyceae } & \multicolumn{2}{|c|}{ Bacillariophyceae } & \multicolumn{2}{|c|}{ Euglenophyceae } & \\
\hline & Range (o/L) & Average & Range (o/L) & Average & Range (o/L) & Average & Range (o/L) & Average & \\
\hline 1 & $765-3464$ & 2398 & 964-2998 & 1528 & $774-2686$ & 1755 & $414-988$ & 644 & 75849 \\
\hline 2 & $684-3945$ & 2377 & $754-2464$ & 1195 & $678-2546$ & 1584 & $248-824$ & 515 & 68056 \\
\hline 3 & $242-995$ & 605 & $135-425$ & 233 & $185-780$ & 465 & $95-210$ & 157 & 17515 \\
\hline 4 & $698-1625$ & 1223 & $565-1465$ & 985 & $310-1045$ & 735 & $188-656$ & 300 & 38915 \\
\hline
\end{tabular}

Table 3. Algal species recorded at 4 stations of Tungabhadra River from May 2004 to April 2005.

\begin{tabular}{|c|c|c|c|c|c|}
\hline \multirow{2}{*}{ Species } & \multicolumn{4}{|c|}{ Tungabhadra river station } & \multirow{2}{*}{ Total algal population $(\mathrm{o} / \mathrm{L})$} \\
\hline & 1 & 2 & 3 & 4 & \\
\hline Chlorophyceae & 64 & 76 & 59 & 69 & 268 \\
\hline Cyanophyceaea & 80 & 59 & 46 & 40 & 225 \\
\hline Bacillariophyceae & 44 & 41 & 33 & 38 & 156 \\
\hline Euglenophyceae & 15 & 10 & 08 & 12 & 45 \\
\hline Total species & & & & & 664 \\
\hline
\end{tabular}

and average populations, rather cell counts of 4 groups of algae at four stations are shown in Table 2. The algal composition of four groups of algae of the river is shown in Table 3. Correlation coefficients ( $r$ value) have been studied to find out the inter-correlation among various physicochemical parameters and algal groups which are given in Table 5. Variations of water temperature were well marked with respect to different seasons. Temperature plays an important role in controlling the abundance of phytoplankton (Singh, 1960). The maximum $\mathrm{pH}$ value of 7.57 was recorded in June at station S3 and maximum of 8.10 in October at station $\mathrm{S} 1$. pH of river water was observed to be in the range of 7.57 to 8.1 indicating alkalinity throughout the period of study. Generally, pH of water promotes the growth of algae (Geroge, 1961). In the present study, higher values of $\mathrm{pH}$ were recorded in winter and lower during the monsoon season. Similar observation has been reported by Bandopandhyay and Gopal (1990). The solids remaining in water after filtration are called 'total dissolved solids'. Dissolved solids may be organic or inorganic in nature. Precisely, the dissolved solids are composed mainly of carbonates, bicarbonates, chloride, sulphate, calcium, magnesium, phosphate, nitrate, sodium, potassium and iron (Trivedy and Goel, 1986). Study indicates that the total dissolved solids contents vary from 129.27 to $357.45 \mathrm{mg} / \mathrm{l}$. The maximum concentrations of total dissolved solids were recorded at station S3 in monsoon, and minimum was estimated at station $\mathrm{S} 1$ in winter. The maximum values of total dissolved solids during monsoon might be due to the gradual increase in the entry of domestic sewage, detergents and industrial waste to the river stream as reported earlier by Gonzalves and Joshi (1946).

Langenegger (1990) and Edet (1993) have described the importance of 'electrical conductivity'. Values of electrical Conductivity obtained during the study are from 235.04 to 595.76 umohs $/ \mathrm{cm}$ (Table 1). There occurred seasonal and spatial variations with minimum value at station S1 during monsoon, and maximum value at station S4 during pre-monsoon season. Dissolved oxygen content is important for direct need of many organisms and affects the solubility and availability of many nutrients, therefore, the productivity of Wetzel(1983) aquatic ecosystem is related to oxygen concentration (Wetzel, 1983). During the present study, lowest average value of dissolved oxygen of $6.80 \mathrm{mg} / \mathrm{l}$ was obtained at 
Table 4. List of identified phytoplankton species in the Tungabhadra River from May 2004 to April 2005.

\begin{tabular}{llllllll}
\hline S. No & Chlorophyceae & S. No & Bacillariophyceae & S. No & Cyanophyceae & S. No & Euglenophyceae \\
\hline 1 & Chlorell sp. & 1 & Nitschia sp. & 1 & Spirulina sp. & 1 & Euglena sp. \\
2 & Clesteriom sp. & 2 & Navicula sp. & 2 & Microcystis sp. & 2 & Pahcus sp. \\
3 & Cosmarium sp. & 3 & Cyclotella sp. & 3 & Phermidium sp. & 3 & Euglena minuta \\
4 & Pediastrum duplex & 4 & Amphora sp. & 4 & Lyngbya sp. & 4 & Euglena spirogyra \\
5 & Scenedesmus sp. & 5 & Pinnularia sp. & 5 & Phormodium & 5 & Trachelomonas sp. \\
6 & Spirogyra sp. & 6 & Diatoma sp. & 6 & Anabaena & 6 & Euglena proxima \\
7 & Ulotrix sp. & 7 & Fragilaria & 7 & Oscillotoria & & \\
8 & Kirchineriella sp. & 8 & Melosires & 8 & Nostoc sp. & & \\
9 & Glosterium & 9 & Nitschia & 9 & Spirulina sp. & & \\
10 & Ankistrodesmus sp. & 10 & Nitschia sp. & 10 & Gomphonema sp. & & \\
11 & Pediastrum simplex & 11 & Lyngbya sp. & & & & \\
12 & Microspotrum sp. & 12 & Spirulina sp. & & & & \\
13 & Coelastrum sp. & & & & & & \\
14 & Schroderia sp. & & & & & & \\
15 & Tetrastrum $\mathrm{sp}$. & & & & & & \\
\hline
\end{tabular}

Table 5. The correlation coefficient values among certain physico-chemical parameters of Tungabhadra River from May 2004 to April 2005.

\begin{tabular}{lccccc}
\hline $\begin{array}{l}\text { Pahysico-chemical } \\
\text { characteristic }\end{array}$ & \multicolumn{4}{c}{ Phytoplankton group } & $\begin{array}{c}\text { Total } \\
\text { phytoplankton }\end{array}$ \\
\cline { 2 - 5 } Temperature & Chlorophyceae & Cyanophyceae & Bacilariophyceae & Euglenophyceae & -0.31 \\
pH & $0.92^{* *}$ & $0.78^{\star *}$ & -0.06 & -0.48 & 0.34 \\
Turbidity & -0.60 & 0.52 & -0.04 & 0.26 & 0.02 \\
Electrical conductivity & 0.01 & -0.09 & 0.18 & 0.16 & $0.68^{\star}$ \\
Dissolved oxygen & 0.45 & 0.42 & -0.19 & 0.25 & 0.38 \\
Biological oxygen demand & -0.14 & 0.58 & -0.42 & -0.35 & 0.21 \\
Chemical oxygen demand & 0.14 & -0.23 & 0.31 & 0.08 & 0.10 \\
Nitrates & 0.05 & -0.13 & 0.11 & 0.12 & -0.28 \\
Chlorides & 0.58 & -0.28 & -0.34 & -0.62 & 0.08 \\
Sulphates & 0.04 & 0.21 & -0.29 & -0.59 & 0.41 \\
Total dissolved solids & 0.22 & 0.52 & -0.26 & -0.18 & 0.05 \\
Phosphates & $-0.75^{\star *}$ & 0.42 & 0.12 & -0.25 & 0.44 \\
Total hardness & $-0.72^{* *}$ & 0.61 & 0.14 & -0.05 & 0.21 \\
Calcium & 0.17 & 0.25 & 0.20 & 0.28 & 0.18 \\
Magnesium & 0.17 & 0.26 & 0.19 & 0.24 & 0.19 \\
\hline
\end{tabular}

${ }^{* *}<0.01,{ }^{*}<0.05$.

station S3 and the highest value of dissolved oxygen of $8.10 \mathrm{mg} / \mathrm{l}$ was recorded at station S1. Higher dissolved oxygen indicates abundant growth of phytoplankton (De et al, 1991) and of related zooplankton leading to higher biological activity. A low content of dissolved oxygen is a sign of organic pollution, tolerance limit of dissolved oxygen is not less than $6 \mathrm{mg} / \mathrm{l}$ (Kudesia, 1985). The factors affecting the oxygen balance in water bodies are: input due to atmosphere and photosynthesis and out put from respiration, decomposition and mineralization of organic matter losses the oxygen to atmosphere. Hence, the oxygen balance in water becomes poorer as the input oxygen at the surface and photosynthetic activities of heterotrophs are enhanced.

Biochemical oxygen demand (BOD) is the most important parameter to measure the pollution load in an aquatic system. In the present study, higher value of BOD and COD is reported as 5.28 and $186.42 \mathrm{mg} / \mathrm{l}$ at stations S1 and S3, respectively. Due to oxidation of the organic waste by natural microorganisms' causes high BOD the same trend has been noticed for COD (Basu, 1966). In general, the values of the COD and BOD 
Table 6. Correlation coefficient between the phytoplankton in the study area.

\begin{tabular}{|c|c|c|c|c|c|c|c|c|}
\hline \multirow{2}{*}{$\begin{array}{l}\text { Station } \\
\text { Taxa }\end{array}$} & \multicolumn{4}{|c|}{ Station S1 } & \multicolumn{4}{|c|}{ Station S2 } \\
\hline & Chlorophyceae & Cyanophyceae & Baciileriophyceae & Euglenophyceae & Chlorophyceae & Cyanophyceae & Baciileriophyceae & Euglenophyceae \\
\hline Rotifers & 1.000 & & & & 1.000 & & & \\
\hline Cladocera & -0.088 & 1.000 & & & -0.135 & 1.000 & & \\
\hline Copepoda & 0.319 & 0.462 & 1.000 & & 0.236 & 0.054 & 1.000 & \\
\hline Protozoa & 0.089 & -0.141 & 0.128 & 1.000 & -0.045 & 0.234 & 0.143 & 1.000 \\
\hline Stations & \multicolumn{4}{|c|}{ Station S3 } & \multicolumn{4}{|c|}{ Station S4 } \\
\hline Taxa & Chlorophyceae & Cyanophyceae & Baciileriophyceae & Euglenophyceae & Chlorophyceae & Cyanophyceae & Baciileriophyceae & Euglenophyceae \\
\hline Rotifers & 1.000 & & & & 1.000 & & & \\
\hline Cladocera & -0.049 & 1.000 & & & 0.647 & 1.000 & & \\
\hline Copepoda & 0.018 & 0.524 & 1.000 & & 0.368 & 0.527 & 1.000 & \\
\hline Protozoa & 0.166 & 0.254 & 0.251 & 1.000 & 0.140 & 0.239 & 0.528 & 1.000 \\
\hline
\end{tabular}

${ }^{* *}<0.01,{ }^{*}<0.05$.

are not related since these 2 tests measures 2 different characteristics but on the other hand, if the effluents do not change drastically, the $\mathrm{COD} / \mathrm{BOD}$ ratio for polluted water from mill remain fairly constant (Kshirsagar, 1968). The amount of calcium and magnesium are found relatively higher in all samples. The hardness values are also found in range 80.58 to $97.00 \mathrm{mg} / \mathrm{l}$. This is probably due to addition of domestic sewage, detergents and industrial wastes along the bank of river. Nitrate in water bodies is responsible for the growth of blue green algae (Abdul, 1998); higher concentration of nitrate is an indication of organic pollution and eutrophication. In the present study, relatively low values of nitrate were observed. Nitrate concentration varied between 2.71 to 8.46 $\mathrm{mg} / \mathrm{l}$. The minimum value obtained is at station S4 in monsoon, maximum value is obtained at station S3 during pre-monsoon (Table 1).

Sulphate is an important mineral substance for phytoplankton growth (Boney, 1989). Sulphate enter into the water body from the catchment area through surface run off. Since the study area (Figure 1) is bordered by agricultural lands where sulphate fertilizers are used in plenty, relatively higher concentrations of sulphate observed could be attributed to the runoff from these agricultural lands.

\section{Biological parameters}

In the present study, forty three species of phytoplankton have been recorded of which fifteen belong(s) to Chlorophyceae, twelve to Cyanophyceae, ten to Bacillariophyceae and six to Euglenophyceae (Table 4). The annual periodicity shows Chlorophyceae dominance which constitute $39.60 \%$ of the total phytoplankton species (populations), followed by Cyanophyceae of $28.70 \%$, Bacillariophyceae of $22.1 \%$ and Euglenophyceae of $9.65 \%$. George (1961) observed that high $\mathrm{pH}$ value promotes the growth of algae. Similar results were observed in the present study. It was also observed that the $\mathrm{pH}$ favored the growth of chlorococales as observed by Gonzalves and Joshi (1946) and Zafar (1964). The concentration of 'dissolved oxygen' decreased along the stretch of river from station one to four. This is due to addition of domestic, agricultural and industrial waste. Dissolved oxygen content was higher in rainy and winter season in the present investigation. The results obtained are in agreement with the findings of Singh (1960, 1965). Review of literature revels that there are two types of growth periods for phytoplankton. Many workers have proved that the maximum development of phytoplankton is during summer and minimum in winter (Philipose, 1960; Kumar and Dutta, 1991). Kumar (1990) estimated that the intensity of phytoplankton is grater during summer (post monsoon and winter and is lowest in monsoon) (Saha and Chaudhary, 1985).

The results obtained indicate that maximum density of phytoplankton in Tungabhadra river occur during July and minimum during January in Tungabhadra river during study period. Significant 


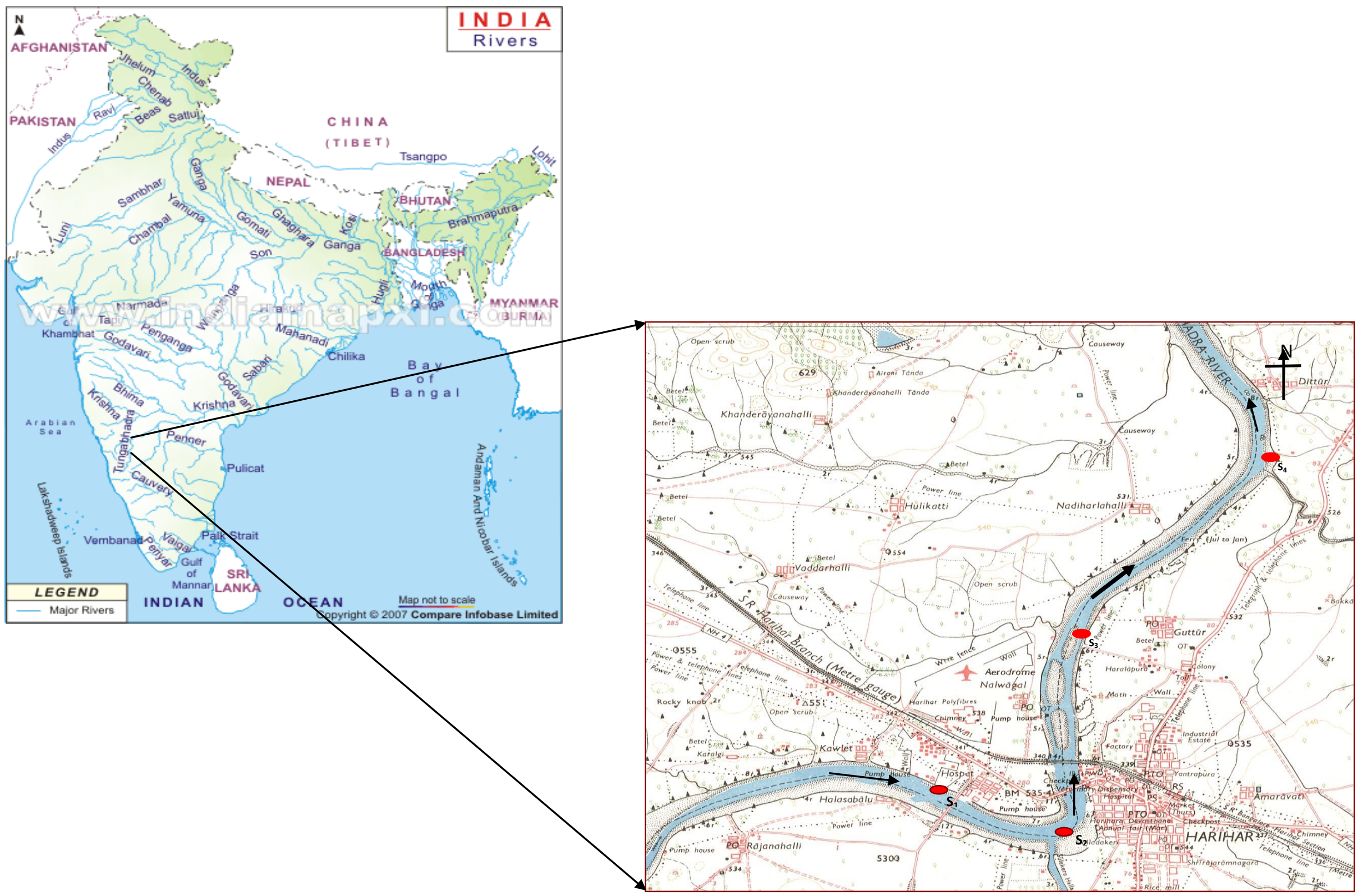

Figure 1. Study area location map of river Tungabhadra in Karnataka, India. 
correlations were estimated between phytoplankton density and physico-chemical parameters of water (Table 5). Cyanaophyceae showed highly significant and positive correlation with temperature and phosphate.

The Chlorophyceae showed significant and negative correlation with $\mathrm{pH}$, dissolved oxygen, total dissolved solids and phosphate; and the Bacillariophyceae showed significant and negative correlation with temperature, $\mathrm{pH}$, dissolved oxygen, nitrates and sulphates. Euglenophyceae showed significant and negative correlations with temperature, dissolved oxygen, nitrates, chlorides, sulphates, total dissolved solids and phosphates. Significant positive correlation was obtained with BOD and COD. The total phytoplankton density showed significant correlation with conductivity. Phytoplankton consume phosphate and inorganic forms of nitrogen in their metabolic activity at different times, thus showing negative correlation.

The present correlations between phytoplankton groups with one or other parameters are in agreement with earlier observations of Anjana (1998), Munawar (1970, 1974) and Verma and Mohanty (1995) (Table 6). Thus, it may be concluded that the density of phytoplankton is dependent on different abiotic factors either directly or indirectly.

\section{Conclusion}

The aforementioned discussion is based on the study of phytoplanktons in Tungabhadra river, studied over a period of one year from May 2004 to April 2005. The water and algal samples were collected at regular intervals of 15 days at four stations for one year.

The results obtained on the limnological parameters are tabulated. The most tolerant genera and species of four groups of algae namely, Chlorophyceae, Bacillariophyceae, Cyanophyceae and Euglenophyceae indicate that total algal population is $17,715 \mathrm{o} / \mathrm{L}$ at station No. 3 , which has the influence of industrial pollution from Harihar Polyfibre and Grasim industry situated on the right bank of the river and discharging its treated effluent to this river. The population of algal species is 75,849 o/L at station S1, 68,056 at station S2 and 38,915 in station S4. Further, it was observed that the annual periodicity shows Chlorophyceae dominance and constituted $39.60 \%$ of the total phytoplankton population which was followed by Cyanophyceae $28.70 \%$, Bacilleriophyceae $22.1 \%$ and Euglenophyceae $9.65 \%$ in the Tungabhadra river throughout the year at selected stations. This may be due to the fluctuation of physico-chemical parameters of the water body in the aforementioned stations.

\section{ACKNOWLEDGEMENTS}

The authors are grateful to the Management of Bapuji Educational Association (R) and Principal, Bapuji Institute of Engineering and Technology, Davangere, for having given magnanimous support, encouragement and facilities. One of the authors is also thankful to National River Conservation Directorate, New Delhi for their financial assistance provided under National River Conservation Programme.

\section{REFERENCES}

Abdul Jameel A (1998). Physico-chemical studies in Uyyakondan Channel water of river Cauvery. Poll. Res. 17(2):111-114.

American Public Health Association (APHA) (1995). Standard methods for examination of water and wastewater Washington D.C. $19^{\text {th }}$ edition.

Anjana S (1998). Seasonal dynamics of phytoplankton population in relation to abiotic factors of freshwater pond at barwani (MP). Poll. Res. 17:133-136.

Basu BK, Pick FR, (1996). Factors regulating phytoplankton and zooplankton development in temperature rivers Limnol. Occangar. 41:1572-1577.

Boney AD (1989). Phytoplankton $2^{\text {nd }}$ ed. Hodder and Stoughton Itd., London.

Desikachary TV (1959). Cyanophyta Indian council of Agriculture Research, New Delhi, pp.1-686.

George MG (1961). Diurnal variations in two shallow ponds in Delhi, India, Hydrobiologia, 18(3):265-273.

Gonzalves EA, Joshi DB (1946). Freshwater algae near Bombay. I the seasonal succession of algae in a tank of Bamdra. J. Bom. Not. Hist. Soc. 46:144-176.

Hassan M (1998). Effect of pond fertilization by broiler droppings on growth performance and meat quality of major carps. Ph.D., thesis, Agric. Univ. Faisalabad, p. 196.

Hendey $\mathrm{NI}$ (1964). An introductory account of smaller algae of British Coastal water V. Bacillariophyceae, H. M. S. O. London.

Kudesia VP (1985). Water Pollution, $2^{\text {nd }}$ Edn. Pragati Prakashana, Meerut, India.

Kumar S (1990). Limnology of Kunjwani pond with reference to plankton and macrophytes. M.Phil., dissertation, University of Jammu, Jammu.

Kumar S, Dutta SPS (1991). Studies on phytoplankton population dynamics in Kunjawani pond, Jammu. Hydrobiol. 7:55-59.

Langenegger O (1990). Ground water quality in rural areas of Westran Africa, UNDP project INTI/81/026/. p. 10.

Munawar M (1970). Limnological studies of fresh water ponds Hydrabad, India I. The biotype Hydrobiologia, 35:127-162.

Munawar M (1974). Limnological studies on fresh water ponds of Hydrabad, India. Hydrobiologia 44:13-27.

Philipose MT (1960). Fresh water phytoplankton of inland fisheries. Proc. symp. Algology, ICAR, New Delhi. pp. 279-291.

Prescott GW (1978). How to know Fresh Water Alage. Third edition. Wm. C. Brown Company USA. pp. 17-280.

Saha IC, Chaudhary SK (1985). Phytoplankton density in relation to abiotic factors of a pond, Bhagalpur Comp. Physiol, Ecol. 10(2):91100.

Singh VP (1960). Phytoplankton ecology of the inland waters of Uttar Pradesh, Proc. Symp Algae ICAR, New Delhi. pp. 243-271.

Smith GM (1950). The fresh water algae of united state. Mc. Graw bill Book Company, New York.

Trivedy RK, Goel PK (1986). Chemical and biological methods for Water Pollution Studies Environ. Publ. Karad, India.

Verma JP, Mohanty RC (1995). Phytoplankton and its correlation with certain physico-chemical parameters of Dhanmukundpur pond. Poll. Res. 14(2):232-242.

Wetzel RG (1983). Limnology, $2^{\text {nd }}$ Edition Saunders college publishing, USA, 767

Zafar AR (1964). On the ecology of algae in certain fish ponds of Hydrabad, India. I. Physico-chemical complex. Hydrobiologia, 23:176-196. 